\section{Harvest Maturity and Storage Temperature Affect Postharvest Quality of 'Wanda' Datil Hot Pepper Grown under Protected Culture}

\author{
Elena E. Lon Kan, Steven A. Sargent ${ }^{1}$, Daniel J. Cantliffe, \\ Adrian D. Berry, and Nicole L. Shaw
}

AdDitional Index wORDs. capsaicinoids, Capsicum chinense, carotenoids, respiration, hydroponic production, specialty vegetable

Summary. Datil hot pepper (Capsicum chinense) has potential for increased production due to its unique, spicy flavor and aroma. However, few reports have been published related to postharvest handling characteristics. The purpose of this study was to determine the effect of harvest maturity on fruit quality under simulated commercial storage conditions. 'Wanda' datil pepper plants were grown hydroponically under protected culture. Fruit were harvested at yellow and orange maturity stages, placed in vented clamshell containers, and stored at 2,7 , or $10^{\circ} \mathrm{C}$ for 21 days. Peppers harvested at yellow stage maintained greater quality than orange peppers during storage at all temperatures. Marketable fruit after 21 days for peppers harvested at the yellow stage was $94 \%\left(2^{\circ} \mathrm{C}\right), 88 \%\left(7^{\circ} \mathrm{C}\right)$, and $91 \%\left(10{ }^{\circ} \mathrm{C}\right)$; that for orange-stage peppers was $68 \%, 74 \%$, and $82 \%$ for the same respective temperatures. No chilling injury (CI) symptoms were observed in these tests. Initial pepper moisture content was $\mathbf{9 0 \%}$, decreasing only slightly during 21 days of storage; weight loss ranged from $2 \%$ to $8 \%$. Soluble solids content (SSC) was greater for peppers harvested at the orange stage $(9.5 \%)$ than for those at yellow stage $\mathbf{( 7 . 8 \% ) . ~ N e i t h e r ~ h a r v e s t ~ m a t u r i t y ~ n o r ~ s t o r a g e ~ t e m p e r a t u r e ~ a f f e c t e d ~ t o t a l ~ t i t r a t a b l e ~}$ acidity (TTA; $0.13 \%$ ) or $\mathrm{pH}(\mathbf{5 . 3})$. Respiration rate varied with temperature but not by harvest maturity and ranged from 12 to $25 \mathrm{mg} \cdot \mathrm{kg}^{-1}$ per hour after 8 days of storage. Peppers harvested orange contained double the amount of total carotenoids as yellow fruit. Carotenoid content for yellow and orange peppers was 58 and $122 \mu \mathrm{g} \cdot \mathrm{g}^{-1}$, respectively. Capsaicinoid content ranged from 1810 to $4440 \mu \mathrm{g} \cdot \mathrm{g}^{-1}$ and was slightly greater for orange-harvested peppers. Datil peppers harvested at the yellow stage and stored in vented clamshell containers had better quality than peppers harvested at the orange stage after 21 days at $2{ }^{\circ} \mathrm{C}$.

$\mathrm{D}$ atil pepper is mostly grown in northeast Florida, especially in the St. Augustine area. It has a long history, most likely originating in northern lowland Amazonia in present-day Peru and brought in the 1700s to the St. Augustine area possibly from Cuba and/or Jamaica (Perry et al., 2007). For generations, it has remained isolated and flourishes in Florida as a backyard crop, with few identified cultivars. Datil pepper is very aromatic and extremely pungent, reminiscent of the related habanero pepper (also Capsicum chinense),

Received for publication 27 Feb. 2019. Accepted for publication 4 Apr. 2019

Published online 12 June 2019.

Horticultural Sciences Department, University of Florida-IFAS, P.O. Box 110690, Gainesville, FL 32611

${ }^{1}$ Corresponding author. E-mail: sasa@ufl.edu.

This is an open access article distributed under the $\mathrm{CC}$ BY-NC-ND license (https://creativecommons.org/ licenses/by-nc-nd/4.0/).

https://doi.org/10.21273/HORTTECH04328-19 although it has a unique, elongated shape. Fruit are typically a bright yellow-golden in color, weigh about $3 \mathrm{~g}$, are 3 to $4 \mathrm{~cm}$ long, and have a characteristic sweet and spicy flavor (Shaw et al., 2008).

In a previous study, four cultivars (Sensation, Terra Time, Wanda, and Super Datil) were cultivated under passively ventilated greenhouse conditions at the University of Florida, Institute of Food and Agricultural Sciences (IFAS) Protected Agriculture Project in Citra, FL, to find a suitable plants for year-round greenhouse production of datil peppers (Shaw et al., 2008). It was reported that the cultivars Wanda and Super Datil Pepper (a commercial cross between datil and another pepper) retained good quality and marketability up to 14 $\mathrm{d}$ at $5{ }^{\circ} \mathrm{C}$ plus $\mathrm{l} \mathrm{d}$ at $20{ }^{\circ} \mathrm{C}$ when harvested at yellow stage (Lon Kan et al., 2007a). No CI was evident during storage at 5 or $10^{\circ} \mathrm{C}$. Increases in lutein, beta-carotene, and total carotenoids contents were reported as 'Wanda' fruit ripened on the plant from green to orange; fruit harvested at the yellow and orange stages were more flavorful and had greater total carotenoids and lutein levels than those harvested at earlier maturities (Lon Kan et al., 2007b).

The purpose of this study was to build on these previous tests (Lon Kan et al., 2007a, 2007b) by assessing changes in selected postharvest quality parameters of 'Wanda' datil peppers harvested at yellow and orange maturity stages and stored at temperatures with potential to induce CI.

\section{Materials and methods}

The locally obtained datil pepper cultivar Wanda (W. Chapman, Jacksonville, FL) was grown in soilless culture using standard production techniques in a passively ventilated greenhouse at the University of Florida/IFAS Protected Agriculture Project in Citra, FL (Shaw et al., 2007). This cultivar was chosen because it has a phenotype typical of datil peppers grown in the region. Peppers were hand-harvested in two seasons (Season 1: June 2007, Season 2: May 2010 ), at yellow and orange ripeness stages and immediately transported in an air-conditioned vehicle within 30 min to the Postharvest Horticulture Laboratory at the University of Florida in Gainesville. Fruit were sorted by size $(40-43 \mathrm{~mm}$ length and 14$16 \mathrm{~mm}$ diameter at the equator) and uniform color. In Season 1, peppers

\begin{tabular}{llll}
\hline $\begin{array}{l}\text { Units } \\
\text { To convert U.S. to SI, } \\
\text { multiply by }\end{array}$ & U.S. unit & SI unit & $\begin{array}{l}\text { To convert SI to U.S., } \\
\text { multiply by }\end{array}$ \\
\hline 29.5735 & fl oz & $\mathrm{mL}$ & 0.0338 \\
2.54 & inch(es) & $\mathrm{cm}$ & 0.3937 \\
25.4 & inch(es) & $\mathrm{mm}$ & 0.0394 \\
28.3495 & $\mathrm{oz}$ & $\mathrm{g}$ & 0.0353 \\
1 & $\mathrm{ppm}$ & $\mathrm{mg} \cdot \mathrm{kg}^{-1}$ & 1 \\
1 & $\mathrm{ppm}$ & $\mathrm{mg} \cdot \mathrm{L}^{-1}$ & 1 \\
1 & $\mathrm{ppm}$ & $\mu \mathrm{\mu g} \cdot \mathrm{g}^{-1}$ & 1 \\
$\left({ }^{\circ} \mathrm{F}-32\right) \div 1.8$ & ${ }^{\circ} \mathrm{F}$ & ${ }^{\circ} \mathrm{C}$ & $\left({ }^{\circ} \mathrm{C} \times 1.8\right)+32$
\end{tabular}




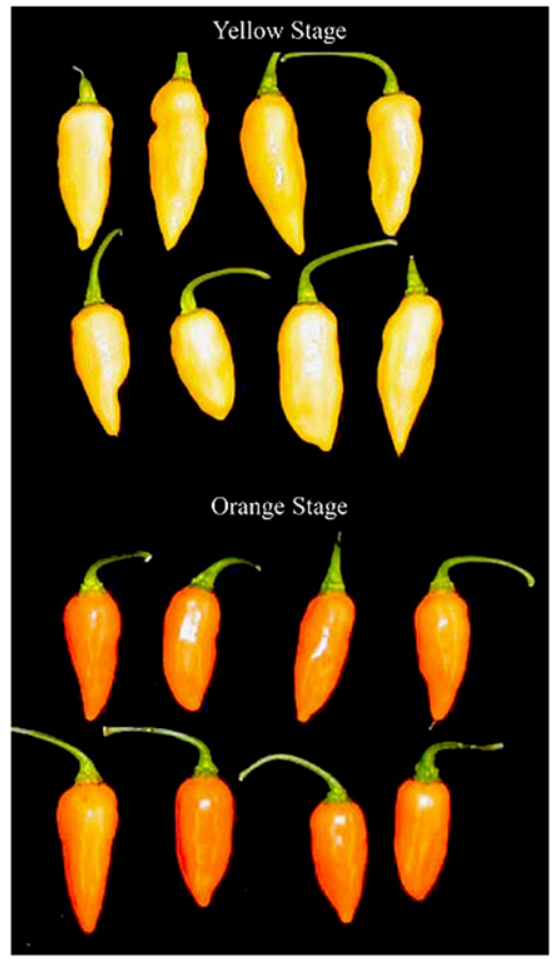

Fig. 1. Datil pepper ripeness stages harvested at yellow (top) and orange (bottom).

were packed ( $\mathrm{n}=24$ fruit) into vented clamshell containers $[85 \times 80 \times$ $70 \mathrm{~mm}$ (Ultrapac 3535-1; Pactiv, Lake Forest, IL)] with two clamshells per temperature/storage time/ripeness stage. In Season 2, peppers were stored ( $\mathrm{n}=15$ fruit) in vented clamshells [127 × 111 × $32 \mathrm{~mm}($ A9756; Pactiv)] with three clamshells per temperature/storage time/ripeness stage. For both seasons, peppers from each ripeness stage (Fig. 1) were stored at 2,7 , or $10{ }^{\circ} \mathrm{C}$ with $91 \%$ to $95 \%$ relative humidity; quality was assessed after 7, 14, and $21 \mathrm{~d}$. In Season 1 , two clamshells were removed per evaluation and the fruit were randomized into three groups of 16. In Season 2, each clamshell $(\mathrm{n}=$ 3 ) containing 15 peppers was used as a replicate for each evaluation.

OVERALL APPEARANCE. Each clamshell was subjectively rated for overall appearance based on a scale of 1 to 5 , where 5 = field fresh, highly marketable with shiny/glossy appearance; 4 good, no surface shriveling but some stem shriveling; 3 = fair, minimal surface shriveling and limit of marketability; 2 = poor, obvious surface shriveling, softening, and unmarketable; and 1 = severe, serious surface shriveling, and/or decay. For each clamshell, percent marketable fruit was calculated by dividing the number of fruit rated $\geq 3$ by the total number of fruit; the number of peppers showing shrivel, black lesions, or decay was recorded.

Moisture CONTENT AND WEIGHT LOss. Moisture content was determined for initial samples $(\mathrm{n}=3$ whole fruit, calyx removed) and for fruit from each storage temperature at $0,7,14$, and $21 \mathrm{~d}$. Samples were sliced, mixed, weighed (2-3 g) into an aluminum pan, dried at $70{ }^{\circ} \mathrm{C}$ for about $2 \mathrm{~d}$ until a constant, final dry weight was obtained (AOAC International, 2000); percent moisture content was calculated [fresh weight basis (FWB)]. Clamshell weight was tracked during storage and percent weight loss was calculated.

Respiration Rate. Four datil fruit were placed in each of 292 $\mathrm{mL}$ glass containers $(\mathrm{n}=3)$ then stored for $16 \mathrm{~d}$ at $2,7,10$, and $13{ }^{\circ} \mathrm{C}$ with loose caps. At each sample time, container lids (fitted with rubber septa) were sealed for $\mathrm{l}$ to $5 \mathrm{~h}$ before headspace sampling to allow for sufficient accumulation of respiratory carbon dioxide $\left(\mathrm{CO}_{2}\right)$, without exceeding $1 \%$. Three headspace samples $(0.5 \mathrm{~mL})$ were withdrawn per container and injected into a gas chromatograph $(580 \mathrm{se}-$ ries; Gow-Mac Instruments, Bridgewater, NJ), equipped with a thermal conductivity detector; final values were expressed as milligrams $\mathrm{CO}_{2}$ per kilogram per hour.

SSC, TTA, AND PH. Initial samples of peppers were frozen at $-30^{\circ} \mathrm{C}$ the day of harvest and after each evaluation for later analysis. Upon thawing, a composite was made from sliced, whole fruit with calyx removed and blended for 2 min (model 908; Hamilton Beach, Washington, NC). Blended tissue samples (15 g) were then homogenized with $30 \mathrm{~mL}$ of deionized water using a polytron (PowerGen 700; OMNI, Kennesaw, GA) for about $1 \mathrm{~min}$ and centrifuged at $17,600 g_{\mathrm{n}}$ for $25 \mathrm{~min}$. SSC [ percent (measured as ${ }^{\circ}$ Brix)] was determined using a refractometer with temperature compensation (Abbe Mark II model 10480; Cambridge Instruments, Buffalo, NY). TTA and $\mathrm{pH}$ were determined by diluting $6 \mathrm{~g}$ of juice with $50 \mathrm{~mL}$ of deionized water and titrating with $0.1 \mathrm{~N}$ sodium hydroxide using an automatic titrimeter
(719 Titrino; Metrohm, Herisau, Switzerland). Results for TTA were expressed in percent citric acid.

Total CarotenoId CONTENT AND CAPSAICINOID CONTENT. Total carotenoid content was determined according to Talcott and Howard (1999) with some modifications. Blended pepper tissue ( $1 \mathrm{~g})$ was homogenized with $20 \mathrm{~mL}$ of ethanolhexane $(1: 1)$ containing $200 \mathrm{mg} \cdot \mathrm{L}^{-1}$ butylated hydroxytoluene and frozen $\left(-20^{\circ} \mathrm{C}\right)$ overnight. The hexane layer was retained and $10 \mathrm{~mL}$ of deionized water was added, vortexed, then frozen $\left(-20{ }^{\circ} \mathrm{C}\right)$ overnight. The hexane extract was measured using a spectrophotometer (Powerwave XS2; BioTek, Winooski, VT) at $436 \mathrm{~nm}$. Total carotenoids were calculated according to Gross (1991) using the equation $\left(\mathrm{AV} \times 10^{6}\right) /\left(\mathrm{A}^{1 \%} \times 100 \mathrm{G}\right)$, where $A$ is the absorbance at $436 \mathrm{~nm}$, $\mathrm{V}$ is the total volume of extract, $\mathrm{A}^{1 \%}$ is the extinction coefficient for a mixture of solvents arbitrarily set at 2500 , and $\mathrm{G}$ is the sample weight (grams).

Total capsaicinoid content was determined using modified methods of Attuquayefio and Buckle (1987). The blended tissue $(10 \mathrm{~g})$ and $10 \mathrm{~mL}$ of acetonitrile were homogenized at high speed for 2 min using a polytron (PowerGen 700) until an emulsion with a creamy appearance was formed. The homogenate was then filtered (no. 8 filter paper) and frozen $\left(-20{ }^{\circ} \mathrm{C}\right)$ overnight to freeze out any water. After thawing, the acetonitrile remaining in the vial was diluted with $9 \mathrm{~mL}$ of deionized water and injected into a conditioned $\mathrm{Cl} 8$ cartridge (Sep-Pak Classic; Waters, Milford, MA). To condition the Cl8 cartridge, $5 \mathrm{~mL}$ of acetonitrile followed by $5 \mathrm{~mL}$ of deionized water was pushed through the cartridge. The capsaicinoids remained in the $\mathrm{Cl} 8$ cartridge, whereas the diluted acetonitrile was discarded. The capsaicinoids were eluted from the cartridge by $4 \mathrm{~mL}$ of acetonitrile followed by 1 $\mathrm{mL}$ of acetonitrile containing $1 \%$ acetic acid. This elution was used to quantify total capsaicinoids with a spectrophotometer (Powerwave XS2) at $280 \mathrm{~nm}$ (Davis et al., 2007) and capsaicinoids standard curve. Total capsaicinoid content was calculated in micrograms per grams FWB.

Data analysis. The experiments were set up using a completely randomized block design 


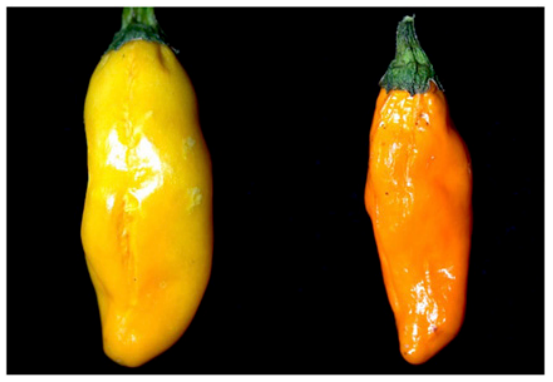

Fig. 2. Shriveling of datil peppers harvested at yellow stage (left) and orange stage (right) after $21 \mathrm{~d} 7{ }^{\circ} \mathrm{C}$ $\left(44.6^{\circ} \mathrm{F}\right)$.

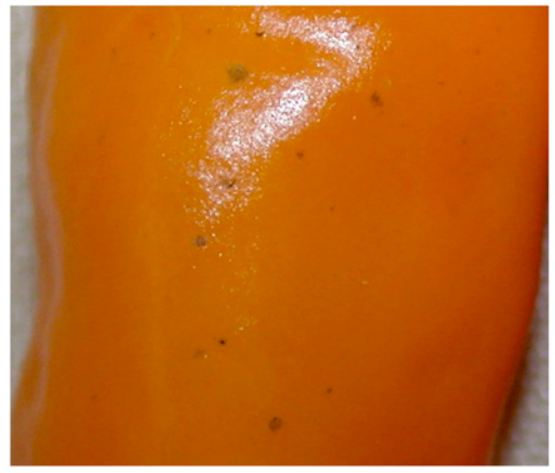

Fig. 3. Black spots on datil peppers harvested at the orange stage after 21 d $7{ }^{\circ} \mathrm{C}\left(44.6{ }^{\circ} \mathrm{F}\right)$.

where temperature represents the block and data were analyzed using SAS software (version 9.4; SAS Institute, Cary, NC). Significant differences between means were separated using Duncan's multiple range test $(P \leq 0.05)$. There were no significant differences between seasons for the parameters evaluated, so the data for both seasons were combined and averaged.

\section{Results and discussion}

There were more marketable peppers (appearance rating $\geq 3$ ) after $2 \mathrm{l} \mathrm{d}$ for fruit harvested at the yellow stage. During storage at 2, 7, or $10{ }^{\circ} \mathrm{C}$, there were, respectively, $94 \%, 88 \%$, and $91 \%$ marketable yellow-harvested peppers and 68\%, $74 \%$, and $82 \%$ orange-harvested peppers (data not shown). The decrease in appearance ratings during storage was due to senescence and moisture loss. After $7 \mathrm{~d}$ at 2,7 , or $10^{\circ} \mathrm{C}$, only a few pepper fruit exhibited any visual defects, mainly shriveling of the stem. However, after 14 and 21 $\mathrm{d}$, shriveling was the main visual defect observed, regardless of storage temperature (Fig. 2).

After $21 \mathrm{~d}$ storage at 7 or $10^{\circ} \mathrm{C}$, small brown/black lesions ( $1-5 \mathrm{~mm}$ in diameter) were present on several fruit (Fig. 3). Black lesion distribution at 7 and $10{ }^{\circ} \mathrm{C}$ was, respectively, $20 \%$ and $13 \%$ (yellow stage) and $7 \%$ and $20 \%$ (orange stage) (data not shown). These abiotic lesions extended through the pericarp wall, as observed previously for 'Wanda' and 'Super Datil' fruit stored for $14 \mathrm{~d}$ at $5^{\circ} \mathrm{C}$ plus $4 \mathrm{~d}$ at $20^{\circ} \mathrm{C}$ (Lon Kan et al., 2007a). Fruit exhibiting more than a single, l-mm-diameter lesion were considered unmarketable. Although similar lesions were previously reported as pepper speck on bell pepper with an unknown cause (Cantwell, 1996; Gonzales-Aguilar, 2014), development at temperatures greater than $5{ }^{\circ} \mathrm{C}$ may be attributed to the Maillard reaction, a nonenzymatic browning reaction between amino acids and reducing sugars.

Previous reports cited sweet peppers (Capsicum sp.), habanero, and other hot peppers as susceptible to CI, with typical symptoms as pitting, scald, and water soaking when stored at temperatures less than $7^{\circ} \mathrm{C}$ (Ashby, 2000; McGregor, 1989; Welby and McGregor, 2004). Sensitivity to chilling temperatures varies with the pepper type and fruit ripeness. For example, chili peppers (Capsicum sp.) were less chilling-sensitive than bell peppers (Capsicum annuum) (Cantwell, 2009), and green bell peppers were more chilling-sensitive than ripe bell peppers (Gonzales-Aguilar, 2014 ). In contrast, datil peppers harvested at green stage shriveled during storage at $5{ }^{\circ} \mathrm{C}$ but did not exhibit CI symptoms (Lon Kan et al., 2007b). In the present study, datil peppers harvested at yellow and orange stages did not exhibit CI symptoms during 21 d storage at 2,7 , or $10^{\circ} \mathrm{C}$. Ripe fruit typically are less susceptible to developing CI symptoms during storage than immature fruit; ripe fruit are more resistant to moisture loss due to a well-developed cuticle.

Fruit weight loss during storage was unaffected by harvest maturity or storage temperature; combined means were $2.09 \%, 5.02 \%$, and $8.03 \%$ after 7,14 , and $21 \mathrm{~d}$, respectively (Table 1). Similarly, neither harvest stage nor storage temperature affected fruit moisture content. Initial moisture content was $89.6 \%$ and after $21 \mathrm{~d}$ the overall means were $81.7 \%$, $86.7 \%$, and $83.7 \%$ for 2,7 , and $10^{\circ} \mathrm{C}$, respectively (Table 1). Previously, Lon Kan et al. (2007a) reported almost double the weight loss in 'Wanda' datil pepper after $14 \mathrm{~d}$ at $10{ }^{\circ} \mathrm{C}$ plus $4 \mathrm{~d}$ at $20{ }^{\circ} \mathrm{C}(10 \%)$, although moisture content was similar to that found in the present study $(82.8 \%)$.

The respiration rate of datil peppers demonstrated a nonclimacteric pattern, typical of that reported for other pepper types; it was slightly greater for orange peppers and increased proportionally with storage temperature (Fig. 4). During storage for $16 \mathrm{~d}$, respiration rates for fruit held at 7 or $10^{\circ} \mathrm{C}$ ranged from 12 to $25 \mathrm{mg} \cdot \mathrm{kg}^{-1}$ per hour but remained constant for fruit held at $2{ }^{\circ} \mathrm{C}(12$ $\mathrm{mg} \cdot \mathrm{kg}^{-1}$ per hour). Respiration rates at 7 or $10{ }^{\circ} \mathrm{C}$ were similar to those reported in previous research with datil pepper (Lon Kan et al., 2007a) and for C. annum at $5{ }^{\circ} \mathrm{C}$ ( GonzalezAguilar, 2014).

Initial SSC values were $18 \%$ greater in orange-harvested peppers $(9.45 \%)$ compared with yellow (8.25\%) (Table $2)$. Several days are necessary for datil peppers to ripen from yellow to orange on the plant, sufficient time to accumulate additional sugars, as was reported for grape tomatoes (Solanum lycopersicum var. cerasiforme), another small Solanaceae fruit (Roberts et al., 2002). Storage temperature and storage time did not affect SSC. By day 21 , SSC for yellow and orange peppers were, respectively, $8.2 \%$ and $9.8 \%$ $\left(2{ }^{\circ} \mathrm{C}\right), 8.5 \%$ and $9.1 \%\left(7^{\circ} \mathrm{C}\right)$, and $7.2 \%$ and $10.5 \%\left(10{ }^{\circ} \mathrm{C}\right.$ ) (Table 2$)$. Núñez-Ramírez et al. (2011) reported SSC values from $8.73 \%$ to $10.16 \%$ for habanero pepper.

TTA values were similar for fruit at both maturity stages and the three storage temperatures (Table 2). There was a slight increase in TTA during storage. After $21 \mathrm{~d}$, TTA values for yellow and orange peppers were $0.310 \%$ and $0.129 \%$, respectively $\left(2{ }^{\circ} \mathrm{C}\right), 0.143 \%$ and $0.145 \%\left(7^{\circ} \mathrm{C}\right)$, and $0.122 \%$ and $0.148 \%\left(10^{\circ} \mathrm{C}\right)$. Jarret et al. (2009) reported high variability for free sugars and organic acids in habanero peppers, suggesting that moderate levels of sugars and organic acids contribute to the typically nonsweet taste. In the present study, the SSC/TTA ratio for orange fruit was 
Table 1. Weight loss and moisture content of datil peppers harvested at yellow and orange stages during storage at 2,7 , or $10{ }^{\circ} \mathrm{C}\left(35.6,44.6\right.$, or $\left.50.0{ }^{\circ} \mathrm{F}\right)$. Data (fresh weight basis) represents the mean $(\mathrm{n}=6)$.

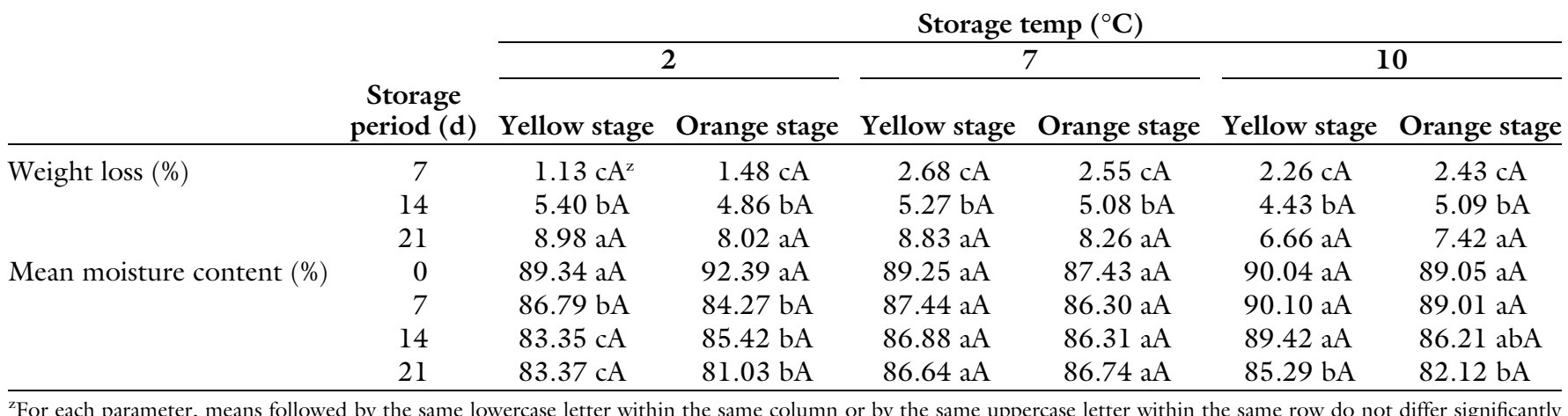
according to Duncan's multiple range test $(P \leq 0.05)$.

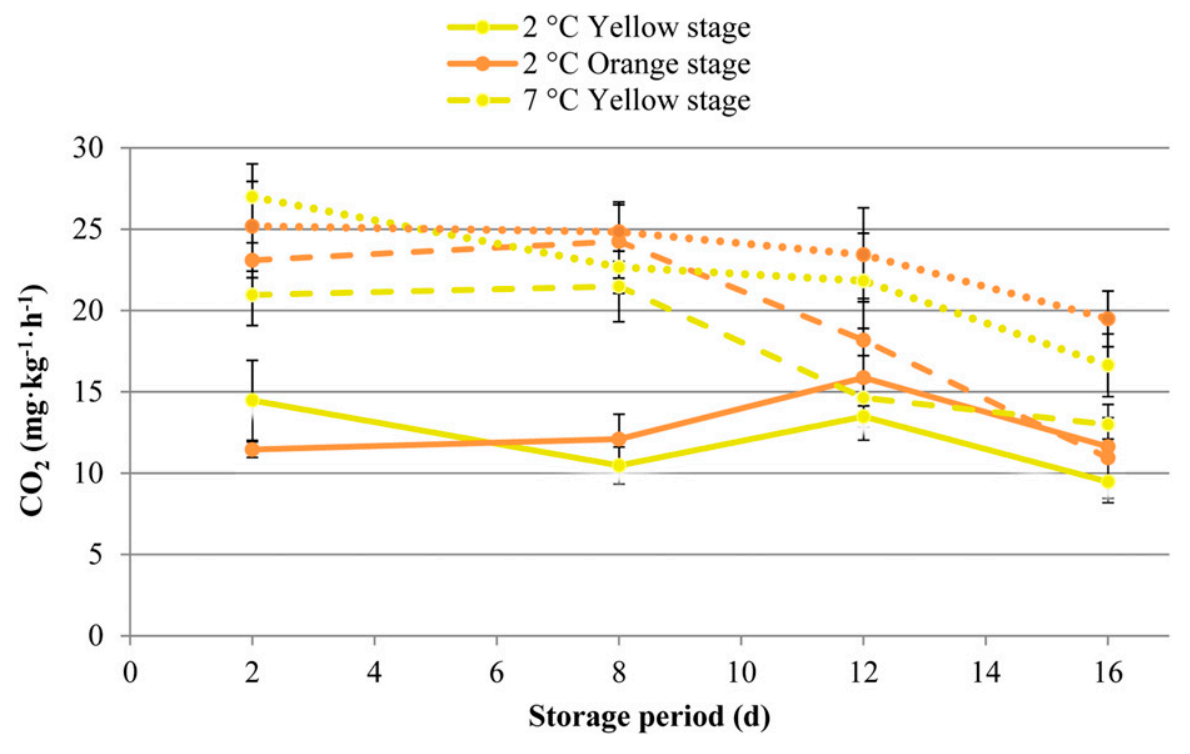

Fig. 4. Respiration carbon dioxide $\left(\mathrm{CO}_{2}\right)$ rates of datil peppers harvested at yellow and orange stages during storage at 2,7 , or $10{ }^{\circ} \mathrm{C}\left(35.6,44.6\right.$, or $\left.50.0{ }^{\circ} \mathrm{F}\right)$. Data represent the mean and $S D(\mathrm{n}=6) ; 1 \mathrm{mg} \cdot \mathrm{kg}^{-1}=1 \mathrm{ppm}$.

greater than that for yellow fruit; however, this ratio generally decreased during storage, coincident with an increase in TTA (Table 2). Pulp pH averaged 5.3 regardless of pepper maturity, storage temperature, or storage period (data not shown).

Total carotenoid content for peppers harvested at the orange stage was almost double that for yellow fruit (Table 2). Although total carotenoids were unaffected by storage temperature, there was an increase during storage. Total carotenoid content for yellow and orange peppers was, respectively, 55.98 and $141.44 \mu \mathrm{g} \cdot \mathrm{g}^{-1}$ $\left(2^{\circ} \mathrm{C}\right), 49.42$ and $98.89 \mu \mathrm{g} \cdot \mathrm{g}^{-1}\left(7^{\circ} \mathrm{C}\right)$, and 67.15 and $124.66 \mu \mathrm{g} \cdot \mathrm{g}^{-1}\left(10^{\circ} \mathrm{C}\right)$ FWB. Wall et al. (2001) evaluated total carotenoids of 25 pepper cultivars that ranged from 1 to $849 \mu \mathrm{g} \cdot \mathrm{g}^{-1}$
FWB. They reported carotenoids concentration for datil pepper as 276 $\mu \mathrm{g} \cdot \mathrm{g}^{-1}$, whereas that for habanero peppers at orange and red stages was 13 and $446 \mu \mathrm{g} \cdot \mathrm{g}^{-1}$, respectively. The authors attributed variations in pigment levels due to differences in cultivar, growing practices and climate, harvest maturity, and postharvest handling.

In the present study, datil peppers harvested at orange stage and stored at 7 or $10{ }^{\circ} \mathrm{C}$ tended to have greater capsaicinoid content than yellow peppers (Table 2). Initial values for capsaicinoid content ranged from 2005 to $3176 \mu \mathrm{g} \cdot \mathrm{g}^{-1}$ FWB for peppers harvested at yellow stage and from 1814 to $3528 \mu \mathrm{g} \cdot \mathrm{g}^{-1}$ FWB for those harvested at orange stage. Capsaicinoid content in orangeharvested fruit increased by $36 \%$ during
$21 \mathrm{~d}$ storage (1814-4440 $\left.\mu \mathrm{g} \cdot \mathrm{g}^{-1} \mathrm{FWB}\right)$, whereas that for yellow fruit remained statistically constant $\left(3176-3159 \mu \mathrm{g} \cdot \mathrm{g}^{-1}\right.$ FWB) over time. Orange-harvested peppers stored at 7 or $10^{\circ} \mathrm{C}$ tended to have greater capsaicinoid content after 0 and $7 \mathrm{~d}$ but had comparable values after 14 and $21 \mathrm{~d}$.

When comparing reported values for capsaicinoids, it is important to determine whether the data were reported on an FWB or a dry weight basis (DWB). For example, capsaicinoid content in habanero pepper was cited to be $1240 \mu \mathrm{g} \cdot \mathrm{g}^{-1}$ FWB and $8840 \mu \mathrm{g} \cdot \mathrm{g}^{-1} \mathrm{DWB}$ (Kurian and Starks, 2002). These authors also studied the variability in capsaicin and dihydrocapsaicin concentrations in habanero pepper and determined that fruit-to-fruit variability of these compounds varied by almost $500 \%$. Therefore, they recommended the use of multifruit samples $(25-100 \mathrm{~g})$ to minimize variability. Giuffrida et al. (2013) reported capsaicinoid content of jalapeno (C. annuum) and habanero to be 1101 and $10,156 \mu \mathrm{g} \cdot \mathrm{g}^{-1} \mathrm{DWB}$, respectively. Datil peppers from the present study had about three times (140\%) more capsaicinoid content as that reported for habanero.

\section{Conclusions and recommendations}

Harvest maturity had the greatest effect on datil pepper quality during storage. Fruit harvested at the yellow stage generally had greater fruit quality than those harvested at the orange stage. Ninety-one percent of fruit harvested at the yellow stage was marketable after $21 \mathrm{~d}$ of storage at 2,7 , or $10^{\circ} \mathrm{C}$, compared with orange-harvested peppers, which 
Table 2. Soluble solids content (SSC), total titratable acidity (TTA), SSC/TTA ratio, total carotenoid concentration, and total capsaicin concentration for datil peppers harvested at yellow and orange stages during storage at 2,7 , or $10{ }^{\circ} \mathrm{C}(35.6$, 44.6, or $50.0^{\circ} \mathrm{F}$ ) for $21 \mathrm{~d}$. Data (fresh weight basis) represent the mean $(\mathrm{n}=6)$.

\begin{tabular}{|c|c|c|c|c|c|c|c|}
\hline & \multirow[b]{3}{*}{$\begin{array}{c}\text { Storage period } \\
\text { (d) }\end{array}$} & \multicolumn{6}{|c|}{ Storage temp $\left({ }^{\circ} \mathrm{C}\right)$} \\
\hline & & \multicolumn{2}{|c|}{2} & \multicolumn{2}{|c|}{7} & \multicolumn{2}{|c|}{10} \\
\hline & & $\begin{array}{l}\text { Yellow } \\
\text { stage }\end{array}$ & $\begin{array}{l}\text { Orange } \\
\text { stage }\end{array}$ & $\begin{array}{l}\text { Yellow } \\
\text { stage }\end{array}$ & Orange stage & $\begin{array}{l}\text { Yellow } \\
\text { stage }\end{array}$ & $\begin{array}{l}\text { Orange } \\
\text { stage }\end{array}$ \\
\hline \multirow[t]{3}{*}{ SSC (\%) } & 0 & $7.83 \mathrm{bB}^{\mathrm{z}}$ & $10.20 \mathrm{aA}$ & $7.03 \mathrm{aA}$ & $8.65 \mathrm{aA}$ & $7.53 \mathrm{aB}$ & $9.1 \mathrm{bA}$ \\
\hline & 7 & $8.08 \mathrm{abB}$ & $9.51 \mathrm{aA}$ & $7.12 \mathrm{aB}$ & $8.53 \mathrm{aA}$ & $7.82 \mathrm{aB}$ & $9.28 \mathrm{abA}$ \\
\hline & 14 & $8.25 \mathrm{abB}$ & $9.43 \mathrm{aA}$ & $7.78 \mathrm{aB}$ & $9.13 \mathrm{aA}$ & $7.68 \mathrm{aB}$ & $10.13 \mathrm{abA}$ \\
\hline & 7 & $0.128 \mathrm{bA}$ & $0.121 \mathrm{aA}$ & $0.122 \mathrm{bA}$ & $0.124 \mathrm{bA}$ & $0.129 \mathrm{aA}$ & $0.13 \mathrm{bA}$ \\
\hline & 14 & $0.127 \mathrm{bA}$ & $0.122 \mathrm{aA}$ & $0.131 \mathrm{abA}$ & $0.137 \mathrm{abA}$ & $0.125 \mathrm{abB}$ & $0.14 \mathrm{abA}$ \\
\hline & 21 & $0.130 \mathrm{bA}$ & $0.129 \mathrm{aA}$ & $0.143 \mathrm{aA}$ & $0.145 \mathrm{aA}$ & $0.122 \mathrm{bB}$ & $0.148 \mathrm{aA}$ \\
\hline \multirow[t]{3}{*}{ SSC/TTA ratio } & 0 & $55.94 \mathrm{bB}$ & $86.47 \mathrm{aA}$ & $55.55 \mathrm{aB}$ & $78.99 \mathrm{aA}$ & $62.15 \mathrm{aB}$ & $83.02 \mathrm{aA}$ \\
\hline & 7 & $65.46 \mathrm{aB}$ & $80.45 \mathrm{abA}$ & $61.25 \mathrm{aB}$ & $71.3 \mathrm{bA}$ & $61.84 \mathrm{aB}$ & $72.52 \mathrm{bA}$ \\
\hline & 14 & $67.50 \mathrm{aB}$ & $79.55 \mathrm{abA}$ & $60.76 \mathrm{aB}$ & $70.2 \mathrm{bA}$ & $64.18 \mathrm{aB}$ & $73.77 \mathrm{bA}$ \\
\hline & 14 & $60.56 \mathrm{bB}$ & $142.47 \mathrm{aA}$ & $51.23 \mathrm{aB}$ & $100.1 \mathrm{aA}$ & $72.8 \mathrm{bB}$ & $128.5 \mathrm{bA}$ \\
\hline & 21 & $61.75 \mathrm{bB}$ & $145.84 \mathrm{aA}$ & $55.36 \mathrm{aB}$ & $113.11 \mathrm{aA}$ & $86.48 \mathrm{aB}$ & $168.18 \mathrm{aA}$ \\
\hline \multirow[t]{4}{*}{ Capsaicin concn $\left(\mu \mathrm{g} \cdot \mathrm{g}^{-1}\right)$} & 0 & 3,176 aA & $1,814 \mathrm{bB}$ & $2,005 \mathrm{bB}$ & 2,398 bA & $2,564 \mathrm{aB}$ & $3,528 \mathrm{bA}$ \\
\hline & 7 & 3,245 aA & $2,097 \mathrm{bB}$ & $2,728 \mathrm{aA}$ & $2,439 \mathrm{bB}$ & $2,854 \mathrm{abB}$ & $3,663 \mathrm{abA}$ \\
\hline & 14 & 3,317 aA & 4,118 aA & $2,824 \mathrm{aA}$ & $2,562 \mathrm{bA}$ & $2,891 \mathrm{abB}$ & $3,790 \mathrm{abA}$ \\
\hline & 21 & 3,678 aA & 4,178 aA & 3,017 aA & 3,465 aA & $3,159 \mathrm{aB}$ & $4,440 \mathrm{aA}$ \\
\hline
\end{tabular}

${ }^{\mathrm{z}}$ For each parameter, means followed by the same lowercase letter within the same column or by the same uppercase letter within the same row do not differ significantly according to Duncan's multiple range test $(P \leq 0.05)$.

${ }^{\mathrm{y}} 1 \mu \mathrm{g} \cdot \mathrm{g}^{-1}=1 \mathrm{ppm}$

had $75 \%$ marketability. Pepper quality and shelf life decreased after $14 \mathrm{~d}$ of storage due to development of shriveling. CI was not observed in any treatment. Orange-harvested fruit were slightly sweeter than yellowharvested, as reflected by $18 \%$ greater SSC:TTA ratio. However, weight loss, TTA, and $\mathrm{pH}$ values were unaffected by harvest maturity or storage period. The capsaicinoid content of datil pepper in this study was greater than reported values for habanero. On the basis of these results, harvest of datil peppers at yellow stage should provide up to $21 \mathrm{~d}$ of acceptable visual and physiochemical fruit quality when stored at $2{ }^{\circ} \mathrm{C}$.

\section{Literature cited}

AOAC International. 2000. Official methods of analysis of AOAC International. 17th ed. AOAC Intl., Gaithersburg, MD.

Ashby, B.H. 2000. Protecting perishable foods during transport by truck. U.S. Dept. Agr. Hdbk. No. 669.

Attuquayefio, V.K. and K.A. Buckle. 1987. Rapid sample preparation method for HPLC analysis of Capsicum fruits and oleoresins. J. Agr. Food Chem. 35:777779.

Cantwell, M. 1996. Bell pepper: Recommendations for maintaining postharvest quality. 29 Oct. 2018 . <http:// postharvest.ucdavis.edu/Commodity_ Resources/Fact_Sheets/Datastores/ Vegetables_English $/$ ?uid $=5 \& d s=799>$.

Cantwell, M. 2009. Chile pepper: Recommendations for maintaining postharvest quality. 29 Oct. 2018. <http:// postharvest.ucdavis.edu/Commodity_ Resources/Fact_Sheets/Datastores/ Vegetables_English / ?uid = 12 \& $\mathrm{ds}=799>$.

Davis, C.B., C.E. Markey, M.A. Busch, and K.W. Busch. 2007. Determination of capsaicinoids in habanero peppers by chemometric analysis of UV spectral data. J. Agr. Food Chem. 55:5925-5933.

Giuffrida, D., P. Dugo, G. Torre, C. Bignardi, A. Cavazza, C. Corradini, and G. Dugo. 2013. Characterization of 12 Capsicum varieties by evaluation of their carotenoid profile and pungency determination. Food Chem. 140:794-802.

Gonzales-Aguilar, G.A. 2014. Pepper. In: K.C. Gross, C.Y. Wang, and M. Saltveit (eds.). The commercial storage of fruits, vegetables and florist and nursery stocks. U.S. Dept. Agr., Agr. Hdbk. No. 66. 29
Oct. 2018. <https://www.ars.usda.gov/ is / n p / Com m e rcials torage/ CommercialStorage.pdf $>$.

Gross, J. 1991. Pigments in vegetables: Chlorophylls and carotenoids. Van Nostrand, New York, NY.

Jarret, R., T. Berke, E. Baldwin, and G. Antonious. 2009. Variability for free sugars and organic acids in Capsicum chinense. Chem. Biodivers. 6:138-145.

Kurian, A.L. and A.N. Starks. 2002. HPLC analysis of capsaicinoids extracted from whole orange habanero chili peppers. J. Food Sci. 67:957-962.

Lon Kan, E.E., S.A. Sargent, A. Simonne, D.J. Cantliffe, and N.L. Shaw. 2007a. Changes in the postharvest quality of datil hot peppers as affected by storage temperature. Proc. Florida State Hort. Soc. 120:246-250.

Lon Kan, E.E., S.A. Sargent, A. Simonne, D.J. Cantliffe, and N.L. Shaw. 2007b. Quality characteristics of datil hot pepper harvested at different stages of maturation. HortScience 42:928 (abstr.).

McGregor, B.M. 1989. Tropical products transport handbook. U.S. Dept. Agr., Agr. Hdbk. No. 668

Núñez-Ramírez， F., D. GonzálezMendoza, O. Grimaldo-Juárez, and 
L.C. Díaz. 2011 . Nitrogen fertilization effect on antioxidants compounds in fruits of habanero chili pepper (Capsicum chinense). Intl. J. Agr. Biol. 13: 827-830.

Perry, L., R. Dickau, S. Zarillo, I. Holst, D.M. Pearsall, D.R. Piperno, M.J. Berman, R.G. Cooke, K. Rademaker, A.J. Ranere, J.S. Raymond, D.H. Sandweiss, F. Scaramelli, K. Tarble, and J.A. Zeidler. 2007. Starch fossils and the domestication and dispersal of chili peppers (Capsicum spp. L.) in the Americas. Science 315:986-988.
Roberts, K.P., S.A. Sargent, and A.J. Fox. 2002. Effect of storage temperature on ripening and postharvest quality of grape and mini-pear tomatoes. Proc. Florida State Hort. Soc. 115:80-84.

Shaw, N.L., D.J. Cantliffe, and C.M. Hutchinson. 2007. A new greenhouse crop: History and production of datil pepper. HortScience 42:852 (abstr.).

Shaw, N.L., D.J. Cantliffe, C.M. Hutchinson, S.A. Sargent, and D. Dinkins. 2008. Greenhouse production of the famous St. Augustine hot pepper, the datil (Capsicum chinensis). Proc. Florida State Hort. Soc. 121:230-233.
Talcott, S.T. and L.R. Howard. 1999. Phenolic autoxidation is responsible for color degradation in processed carrot puree. J. Agr. Food Chem. 47:21092115.

Wall, M.M., C.A. Waddell, and P.W. Bosland. 2001. Variation in $\beta$-Carotene and total carotenoid content in fruits of Capsicum. HortScience 36:746-749.

Welby, E.M. and B. McGregor. 2004. Agricultural export transportation handbook. U.S. Dept. Agr., Agr. Hdbk. No. 700. 